\title{
Environmental and Genotypic Variation of Capsaicinoid and Flavonoid Concentrations in Habanero (Capsicum chinense) Peppers
}

\author{
Justin D. Butcher, Kevin M. Crosby ${ }^{1}$, Kil Sun Yoo, \\ and Bhimanagouda S. Patil \\ Vegetable and Fruit Improvement Center, Department of Horticultural \\ Sciences, 1500 Research Parkway, Suite 120A, College Station, TX 77845
}

A.M.H. Ibrahim

Department of Soil and Crop Sciences, 370 Olsen Boulevard, 2474 TAMU, Texas A\&M University, College Station, TX 77843

Daniel I. Leskovar

Vegetable and Fruit Improvement Center, Department of Horticultural Sciences, Texas AgriLife Research Center, 1619 Garner Field Road, Uvalde, TX 78801

\section{John L. Jifon \\ Vegetable and Fruit Improvement Center, Department of Horticultural Sciences, Texas AgriLife Research Center, 2415 E. Highway 83, Weslaco, TX 78596}

Additional index words. phytochemical analysis, capsaicin, dihydrocapsaicin, luteolin, quercetin, genotype $\times$ environment interaction

\begin{abstract}
Habanero peppers have become increasingly popular in the United States for supplying unique flavors and high levels of pungency. As consumption of this product increases, development of improved cultivars with elevated phytochemicals will likely result in additional demand from consumers. This study evaluated fruit size, capsaicinoid, and flavonoid concentrations in six Habanero (Capsicum chinense) genotypes grown at three different Texas locations: College Station, Uvalde, and Weslaco. Five of these Habanero experimental hybrids (H1-red, H2-orange, H3-orange, H5-dark orange, and H6-yellow) were developed at Texas A\&M University with genetic improvement in numerous traits of interest, and Kukulkan $F_{1}$ (Kuk-orange) was included as a commercial control. In general, H1-red had the largest fruits in these locations. Capsaicin and dihydrocapsaicin (DHC) concentrations were highest in Kuk-orange followed closely by H5-dark orange and were lowest in H6-yellow. Fruit at Weslaco was larger and contained more capsaicin and DHC than those produced in Uvalde or College Station. Although flavonoid contents were variable and low in all genotypes and locations, H3-orange showed the most stability for use in future crossing schemes to compete against Kuk-orange for this characteristic. Our results suggest that variation in phytochemicals in fruit tissue of Habanero genotypes can be exploited by selecting in an appropriate environment.
\end{abstract}

Habanero peppers (Capsicum chinense) are a unique group of cultivated plants diversified

\footnotetext{
Received for publication 31 Aug. 2011. Accepted for publication 23 Jan. 2012.

The present research report was based on work supported by the Cooperative State Research, Education, and Extension Service, U.S. Department of Agriculture under Agreement No. 2009-3440219831, "Designing Foods for Health" through the Vegetable \& Fruit Improvement Center, Texas AgriLife Research.

Our gratitude and appreciation includes the work provided by Alfredo Rodriguez and Shinsuke Agehara at the Weslaco and Uvalde AgriLife Centers, respectively.

${ }^{1}$ To whom reprint requests should be addressed; e-mail kcrosby@ag.tamu.edu.
}

in various traits of interest. Fruit color depends on maturity, ranging from light to dark green and then in varying shades of red, yellow, orange, or chocolate (Crosby, 2008). Some Habanero peppers supply a unique fruity flavor and distinct aroma making them popular additions to various dishes (Andrews, 1995; Crosby, 2008; Greenleaf, 1986). Moreover, Habanero peppers are gaining popularity as a potential ingredient in salsa combinations and even serving as a candidate in the industrial extraction of capsaicin for various products (Sanatombi and Sharma, 2008). However, few Habanero pepper breeding programs exist worldwide, limiting the potential exploitation of this diverse germplasm. Despite this fact, success has been achieved in various areas such as nematode resistance (Fery and
Thies, 2006) and quality characteristics such as color, flavor, decreased levels of capsaicin, and elevated $\beta$-carotene content as in TAM Mild Habanero (TMH) (Crosby et al., 2005). Because peppers can contain both capsaicinoids (capsaicin and DHC) and flavonoids (quercetin and luteolin), they provide a good model for examining the potential health benefits of these compounds.

Factors influencing capsaicin content in fruits include genotypic differences, geographical location, fruit maturity, and compartmentalization within fruit (Huffman, 1977; Monforte-Gonzalez et al., 2010). Within fruit tissue, capsaicin is unevenly distributed, concentrated in placental and cross-wall regions (Huffman, 1977). Monforte-Gonzalez et al. (2010) reported that placental regions of fruit possess an ability to channel inorganic forms of nitrogen (nitrate) into secondary metabolites contributing to capsaicin content. Capsaicinoid synthesis and content within fruit tissue occurs more actively between 20 and $40 \mathrm{~d}$ after anthesis as fruits increase in size and maturity (Sukrasno and Yeoman, 1993) with environmental stresses, such as water deficiency, contributing to various levels (Howard, 2001).

Flavonoids have been previously characterized as a group of polyphenolic substances produced as a result of secondary metabolisms (Materska and Perucka, 2005; Ross and Kasum, 2002). They are found in the thylakoid membrane of chloroplasts (Havsteen, 1983). Between 4000 and 5000 different flavonoids have been described (Hollman and Katan, 1999), providing color and flavor to many fruits and vegetables. Factors affecting flavonoid variation in fruits include the genotype, degree of maturity, processing methods, storage conditions (Ross and Kasum, 2002), light, and levels of nitrogen in soils (Amiot-Carlin et al., 2007). In a typical pepper flavonoid analysis, quercetin and luteolin are usually the two most prevalent compounds identified within fruit tissue with values increasing up to $800 \mathrm{mg} \cdot \mathrm{kg}^{-1}$ in different Capsicum annuum genotypes (Howard, 2001; Lee et al., 1995). Results from Lee et al. (1995) also provide evidence that $C$. annuum fruit generally contains higher flavonoid levels than those of $C$. chinense. Howard (2001) suggested a positive correlation generally exists between quercetin and luteolin concentrations in fruit tissue. Other reports from Howard (2001) support the idea that flavonoid contents can decrease continuously during maturation, yet appreciable amounts can still exist when peppers are consumed. According to Pietta (2000), flavonoid intake by humans can vary between 50 and $800 \mathrm{mg} \cdot \mathrm{d}^{-1}$. As Hertog et al. (1992) discussed, more reliable studies are needed to determine the potential role of flavonoids in combating human cancer and occurrence in different foods.

Although many studies have been conducted analyzing capsaicin and flavonoid concentrations in different Capsicum fruits (Contreras-Padilla and Yahia, 1998; Cooper et al., 1991; Harvell and Bosland, 1997; Hertog 
et al., 1992; Howard et al., 2000; Kurian and Starks, 2002; Lee et al., 1995, 2005; Poyrazoglu et al., 2005; Sanatombi and Sharma, 2008; Singh et al., 2009; Zewdie and Bosland, 2000), few studies have actually evaluated Habanero peppers for capsaicin and flavonoid concentrations when grown in different environments. Before this study, our group had limited phytochemical data for these five experimental hybrids. Therefore, our quantitative analyses were intended to reveal potential differences in phytochemical concentrations among them and in comparison with a popular commercial control. To our knowledge, there have not been any reports to date indicating a direct correlation between fruit color or fruit size and phytochemical expression. Because most Habanero studies focus predominantly on capsaicinoid (capsaicin and DHC) expression, we wanted to expand and include two important flavonoids (quercetin and luteolin) routinely found in pepper tissue that have become increasingly linked to human health. Because fruit size has become an important component of commercial pepper production, we also wanted to increase the practical applications for this experiment and accurately portray the size of harvested fruit by measuring fruit weights. Furthermore, we wanted to determine the best environment to enhance the concentrations of these phytochemicals within fruit tissue and ultimately identify good candidates for introduction as new Habanero cultivars.

\section{Materials and Methods}

Plant material. Five advanced Habanero experimental hybrids fixed for various traits of importance to the seed industry and one commercial control were chosen for evaluation. The diverse pedigrees of these genotypes have resulted in variation for fruit color, size, shape, yield, disease resistance, and days to maturity. H1 is a large-fruited, early-maturing, red type with a small plant. $\mathrm{H} 2, \mathrm{H} 3$, and $\mathrm{H} 5$ are orange-fruited types with larger plants and express resistance to Pepper mottle virus and Tomato spotted wilt virus derived from Plant Introduction (PI) 152225 . H6 produces heavy yields of goldenyellow fruit with no pungency on vigorous plants.

Habanero transplants were set out between 1 Mar. and 15 Apr. 2009 at three Texas A\&M AgriLife Research Centers: College Station (sandy clay loam: lat. $30.61^{\circ} \mathrm{N}$, long. $96.32^{\circ} \mathrm{W}$ ), Uvalde ( silty clay loam, fine-silty, mixed, hyperthermic Aridic Calciustoll: lat. $29.22^{\circ} \mathrm{N}$, long. $99.78^{\circ} \mathrm{W}$ ), and Weslaco (Hidalgo fine sandy loam: lat. $26.16^{\circ} \mathrm{N}$, long. $\left.97.98^{\circ} \mathrm{W}\right)$. Fruit harvest took place between late June and Aug. 2009. A subsurface drip irrigation method was used in each location, and commercial agricultural practices typical for Habanero peppers were followed. In an effort to potentially acknowledge the impact of a genotype $\times$ environment interaction with respect to performance of these different genotypes, both within and across these different environmental locations, we also measured five different environmental parameters (maximum and minimum air temperatures, relative humidity, solar radiation, and precipitation) throughout the experiment, as seen in Figures 1 through 4. Being interested in material more for fresh markets, fully colored, matured, fresh fruits were harvested from each of the six separate, $\approx 10$-foot row plots. All fruit specimens were selected that appeared healthy, completely colored, and turgid at the time of harvest. After fruit weights were measured on each genotype, all samples were stored at $-80{ }^{\circ} \mathrm{C}$ until analysis could ensue.

Capsaicinoid extraction and analysis. Capsaicinoids (capsaicin and DHC) were extracted as described by Singh et al. (2009) with some modifications. All extraction procedures used tissue from five fresh, smashed
Average Monthly Air Temperatures $\left({ }^{\circ} \mathrm{C}\right)$

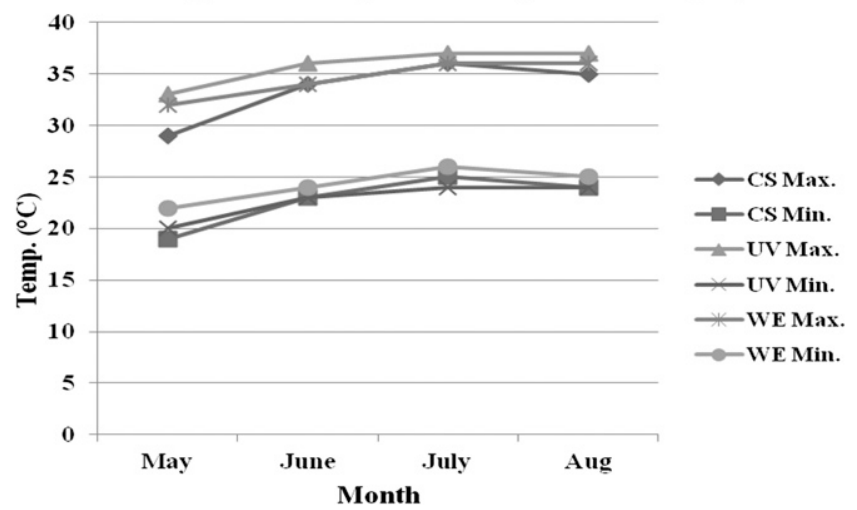

Fig. 1. Average monthly maximum and minimum air temperatures during May to Aug. 2009 in CS (College Station), UV (Uvalde), and WE (Weslaco).

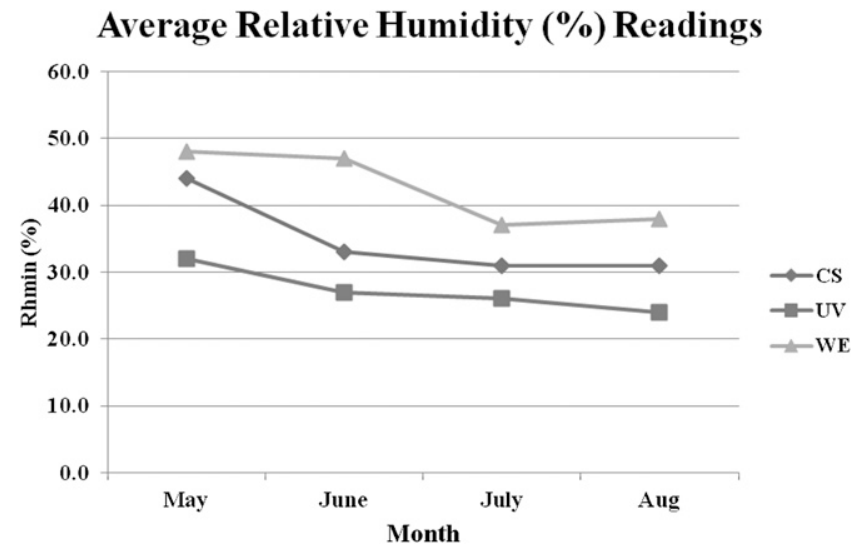

Fig. 2. Average relative humidity readings during May to Aug. 2009 in CS (College Station), UV (Uvalde), and WE (Weslaco).

\section{Average Solar Radiation Readings (MJm-2)}

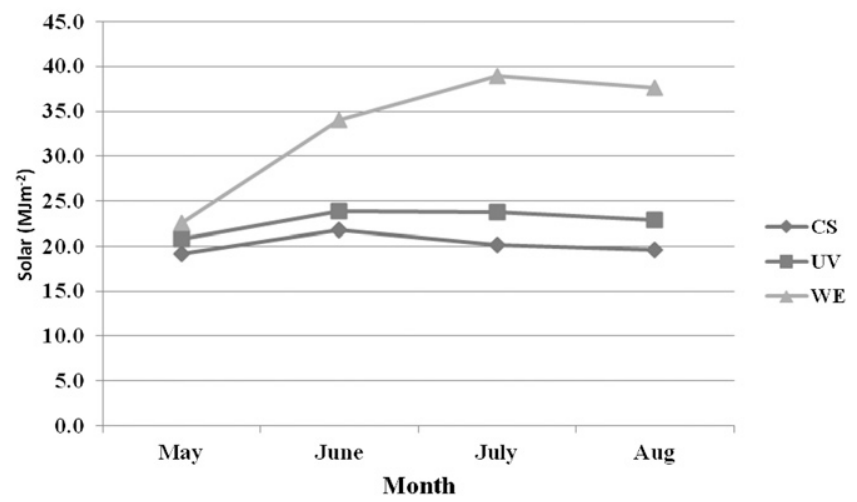

Fig. 3. Average solar radiation readings during May to Aug. 2009 in CS (College Station), UV (Uvalde), and WE (Weslaco). 
pepper fruits mixed with seeds from six separate plants, if possible, for a total of six replications and repeated for the different phytochemical analyses. These frozen fruits were pulverized using a mallet, and $\approx 5 \mathrm{~g}$ of mixed fruit tissue with seeds was taken for each replication. The sample was homogenized in $20 \mathrm{~mL}$ of $100 \%$ methanol using a Polytron PT 10-35 Homogenizer (Kinematica Inc., Bohemia, NY), and final volumes were adjusted to $30 \mathrm{~mL}$. The fruit tissue extract was allowed to precipitate in a $-20{ }^{\circ} \mathrm{C}$ freezer before a sample of supernatant was collected and injected into a high-performance liquid chromatography (HPLC) system. The HPLC system includes a Perkin Elmer Model 200 pump, autosampler, and LC 295 ultraviolet/ Vis detector. Forty microliters from each sample was injected, and the peak area was calculated to determine capsaicin and DHC concentrations on a fresh weight basis. Capsaicin and DHC levels were detected at $280 \mathrm{~nm}$ using a Nova-Pak $\mathrm{C}_{18}(4.6 \times 150$ $\mathrm{mm}, 4 \mu \mathrm{m})$ column with a guard cartridge, and the flow rate was $1.0 \mathrm{~mL} \cdot \mathrm{min}^{-1}$ of $45 \%$ acetonitrile with $0.5 \% \mathrm{H}_{3} \mathrm{PO}_{4}$. External standards of capsaicin $\left(23 \mu \mathrm{g} \cdot \mathrm{mL}^{-1}\right)$ and DHC (14 $\mu \mathrm{g} \cdot \mathrm{mL}^{-1}$ ) were used to quantify the samples.

Flavonoid extraction and analysis. The flavonoid extraction method was similar to that of Lee et al. $(1995,2005)$ with some modifications. Four microliters of each extract used in the capsaicinoid analysis was mixed with $2 \mathrm{~mL}$ of $3 \mathrm{~N}$ hydrochloric acid and hydrolyzed at $90{ }^{\circ} \mathrm{C}$ for $60 \mathrm{~min}$. Flavonoids (quercetin and luteolin) were analyzed by an HPLC system and quantified at $360 \mathrm{~nm}$ using a Nova-Pak $\mathrm{C}_{18}(4.6 \times 150 \mathrm{~mm}, 4 \mu \mathrm{m})$ column with a guard cartridge at a flow rate of $0.8 \mathrm{~mL} \cdot \mathrm{min}^{-1}$. Mobile phase program conditions used Solvent $\mathrm{A}\left(0.5 \% \mathrm{H}_{3} \mathrm{PO}_{4}\right.$ in water $)$ and Solvent $\mathrm{B}\left(0.5 \% \mathrm{H}_{3} \mathrm{PO}_{4}\right.$ in methanol) to increase from $40 \% \mathrm{~B}$ to $100 \% \mathrm{~B}$ in $20 \mathrm{~min}$. The injection volume was $20 \mu \mathrm{L}$, and external standards of quercetin $\left(45.65 \mu \mathrm{g} \cdot \mathrm{mL}^{-1}\right)$ and luteolin $\left(28.82 \mu \mathrm{g} \cdot \mathrm{mL}^{-1}\right)$ were used to quantify the samples.

Statistical analysis. In each location, Habanero genotypes were planted in a completely randomized design. Statistical analyses used a General Linear Model program in SAS (SAS Institute Inc., 2008) to analyze for differences in locations (L), genotypes $(\mathrm{G})$, and location by genotype $(L \times G)$ interactions. Separations were also made by least significant difference (LSD) at the 0.05 level of calculated mean values on six separate replications for genotypes both within and across locations to compare differences in fruit weight, capsaicin, DHC, quercetin, and luteolin. Hartley's homogeneity of variance (HOV) test was also conducted as described by Hoshmand (2006). In addition, a preliminary correlation analysis experiment was conducted among fruit yield, fruit weight, and the two phytochemical groups when a few of the genotypes were selected in the Uvalde location (Table 1). Later, a correlation analysis was conducted simply between total capsaicinoid (capsaicin + DHC) and total flavonoid (quercetin + luteolin) data from all three locations.

\section{Results and Discussion}

Fruit weight. Results of the analysis of variance (ANOVA) revealed significant $\mathrm{L}$ and $\mathrm{L} \times \mathrm{G}$ interactions (Table 2). The
Weslaco location produced larger fruit than the other locations (Table 3), and H1-red had the highest overall mean fruit weight value. H1-red had the largest fruit weights at both College Station and Weslaco but not in Uvalde (Table 3); however, H6-yellow was not significantly different from H1-red. Although Weslaco produced the second largest

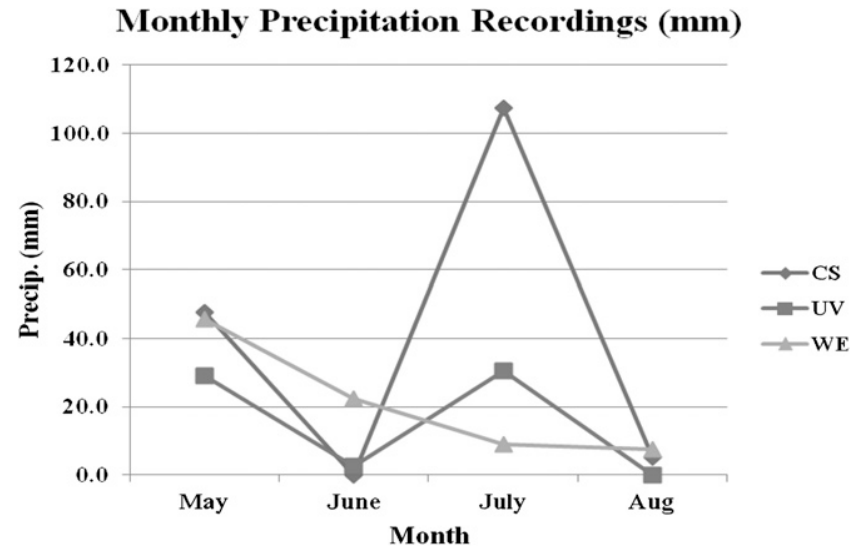

Fig. 4. Average precipitation recordings during May to Aug. 2009 in CS (College Station), UV (Uvalde), and WE (Weslaco).

Table 1. Preliminary data and calculations for average fruit number per plant, percent dry matter, and correlation ( $r$ ) analysis values between fruit yield (FY), fruit weight (FW), flavonoids (quercetin + luteolin), and capsaicinoids (capsaicin + DHC) for four select Habanero (Capsicum chinense) experimental hybrids grown in Uvalde, TX.

\begin{tabular}{lcclrrrr}
\hline Genotype & Fruit no. & Percent dry matter & & \multicolumn{4}{c}{ Correlation analyses } \\
\hline H1-red & $58 \mathrm{ab}^{\mathrm{z}}$ & $16.10 \mathrm{~b}^{\mathrm{z}}$ & & FY & FW & Flav. & Cap. \\
H2-orange & $41 \mathrm{~b}$ & $20.01 \mathrm{a}$ & FY & $1.00^{\mathrm{y}}$ & 0.37 & -0.56 & 0.24 \\
& & & FW & 0.37 & 1.00 & -0.77 & -0.11 \\
H3-orange & $93 \mathrm{ab}$ & $16.85 \mathrm{~b}$ & Flav. & -0.56 & -0.77 & 1.00 & -0.55 \\
H5-dark orange & $102 \mathrm{a}$ & $16.94 \mathrm{~b}$ & Cap. & 0.24 & -0.11 & -0.55 & 1.00 \\
\hline
\end{tabular}

${ }^{\mathrm{x}}$ Mean separations by Duncan at $P \leq 0.05$. Means followed by the same lower case letters are not significantly different.

${ }^{y}$ Signifies no significant associations were detected between any of these components at the $5 \%$ level.

$\mathrm{FY}=$ fruit yield; $\mathrm{FW}=$ fruit weight; Flav. = flavonoids (quercetin + luteolin); Cap. = capsaicinoids (capsaicin + DHC).

Table 2. F-values and their significances when data for five fruit characteristics were analyzed by the main effects (location, genotype) and their interactions.

\begin{tabular}{lcccccc}
\hline Source & df & Fruit wt & Capsaicin & Dihydrocapsaicin & Quercetin & Luteolin \\
\hline Location (L) & 2 & $4.86^{*}$ & $9.13^{*}$ & $2.21 \mathrm{NS}$ & $8.83^{*}$ & $0.54 \mathrm{NS}$ \\
Genotype (G) & 5 & $1.85 \mathrm{NS}$ & $11.37^{*}$ & $14.68^{*}$ & $5.13^{*}$ & $1.62 \mathrm{NS}$ \\
$\mathrm{L} \times \mathrm{G}$ & 9 & $19.25^{* *}$ & $4.68^{*}$ & $3.97^{*}$ & $2.30^{*}$ & $4.13^{*}$ \\
\hline
\end{tabular}

Ns, *, and **: Nonsignificant, significant, and highly significant values at the $5 \%$ level, respectively.

Table 3. Fruit colors and fruit weights of mature Habanero peppers (C. chinense) grown in three Texas locations.

\begin{tabular}{|c|c|c|c|c|}
\hline \multirow[b]{2}{*}{ Genotype } & \multirow[b]{2}{*}{ Fruit color } & \multicolumn{3}{|c|}{ Fruit wt $(\mathrm{g})$} \\
\hline & & College Station & Uvalde & Weslaco \\
\hline Kuk & Orange & $6.11 \mathrm{~cd}^{\mathrm{z}} \mathrm{B}^{\mathrm{y}}$ & NA & $8.87 \mathrm{c} \mathrm{A}$ \\
\hline H1 & Red & 9.51 a B & $7.80 \mathrm{ab} \mathrm{C}$ & $14.43 \mathrm{a} \mathrm{A}$ \\
\hline H2 & Orange & $8.61 \mathrm{ab} A$ & $6.11 \mathrm{~d} \mathrm{~B}$ & $7.71 \mathrm{~d} \mathrm{~A}$ \\
\hline H3 & Orange & $7.51 \mathrm{bc} \mathrm{B}$ & $6.99 \mathrm{c} \mathrm{B}$ & $9.95 \mathrm{~b} \mathrm{~A}$ \\
\hline H5 & Dark Orange & $5.49 \mathrm{~d} \mathrm{~B}$ & $7.22 \mathrm{bc} \mathrm{A}$ & 6.70 e $\mathrm{A}$ \\
\hline H6 & Yellow & $4.79 \mathrm{~d} \mathrm{C}$ & 7.97 a B & $10.24 \mathrm{~b} \mathrm{~A}$ \\
\hline \multicolumn{2}{|c|}{ Overall mean values per location } & 7.00 & 7.22 & 9.65 \\
\hline
\end{tabular}

${ }^{\mathrm{z}}$ Mean separations within each location by LSD at $P \leq 0.05$. Means followed by the same lower case letters are not significantly different.

${ }^{y}$ Mean separations across locations by LSD at $P \leq 0.05$. Means followed by the same upper case letters are not significantly different.

$\mathrm{NA}=$ entry not available in that location; LSD $=$ least significant difference. 
mean fruit weights for both H2-orange (7.71 $\mathrm{g}$ vs. $8.61 \mathrm{~g}$ in College Station) and H5-dark orange (6.70 $\mathrm{g}$ vs. $7.22 \mathrm{~g}$ in Uvalde), their values were not significantly different from the highest value obtained from their alternate location (Table 3 ). In comparison with their respective overall mean values per location, the difference of H1-red's mean value was significantly higher (Table 3 ). Based on market demands for larger fruit, Weslaco may, therefore, be an optimum location to grow high-quality Habanero peppers, and H1-red may have some potential for further studies and potential release as a result of its appealing phenotypic attributes.

Capsaicin and dihydrocapsaicin. The capsaicin data from the ANOVA found significant $\mathrm{F}$-values for $\mathrm{L}, \mathrm{G}$, and the $\mathrm{L} \times \mathrm{G}$ interaction (Table 2), whereas DHC data showed significant F-values for $G$ and the $\mathrm{L} \times \mathrm{G}$ interaction (Table 2). Previous reports from Antonious et al. (2009) observed significant differences existing in fresh fruit of different $C$. chinense PIs they examined (highest PI reached levels of $2.7 \mathrm{mg} \cdot \mathrm{g}^{-1}$ of capsaicin plus dihydrocapsaicin). After separating each genotype across these locations by $\operatorname{LSD}_{(0.05)}$, we verified significant differences as well (Table 4). In general, concentrations were higher in fruit tissue grown at the Weslaco location (Table 4). In nearly all cases, Kukorange produced the highest amount of capsaicin and DHC followed by H5-dark orange

Table 4. Capsaicinoid (capsaicin and dihydrocapsaicin) concentrations in mature Habanero pepper fruits (C. chinense) grown in three Texas locations.

\begin{tabular}{|c|c|c|c|c|c|c|}
\hline \multirow[b]{2}{*}{ Genotype } & \multicolumn{3}{|c|}{ Capsaicin concn $\left(\mu \mathrm{g} \cdot \mathrm{g}^{-1} \mathrm{FW}\right)$} & \multicolumn{3}{|c|}{ Dihydrocapsaicin concn $\left(\mu \mathrm{g} \cdot \mathrm{g}^{-1} \mathrm{FW}\right)$} \\
\hline & $\mathrm{CS}$ & UV & WE & CS & UV & WE \\
\hline$\overline{\text { Kuk- }}$ & $372.25 \mathrm{a}^{\mathrm{z}} \mathrm{A}^{\mathrm{y}}$ & NA & 491.72 a $\mathrm{A}$ & 385.44 a A & NA & 238.29 a B \\
\hline $\mathrm{H} 1$ & $3.34 \mathrm{bc}$ & $32.93 \mathrm{c} \mathrm{B}$ & $154.58 \mathrm{c}$ & 71.41 & $30.78 \mathrm{c} \mathrm{B}$ & $83.23 \mathrm{~d} \mathrm{~A}$ \\
\hline $\mathrm{H} 2$ & $121.81 \mathrm{bc} \mathrm{B}$ & $60.26 \mathrm{~b} \mathrm{~B}$ & $315.85 \mathrm{~b} \mathrm{~A}$ & 80.98 & $62.27 \mathrm{~b} \mathrm{~B}$ & $135.95 \mathrm{c} \mathrm{A}$ \\
\hline $\mathrm{H} 3-\mathrm{c}$ & $71.56 \mathrm{c} \mathrm{A}$ & & $103.46 \mathrm{c} \mathrm{A}$ & A & $7.20 \mathrm{~d} \mathrm{~B}$ & $44.01 \mathrm{~d} \mathrm{~A}$ \\
\hline $\mathrm{k}$ ora & $247.79 \mathrm{ab} B$ & B & 4 a A & 209. & 6 a B & $196.58 \mathrm{~b} \mathrm{AB}$ \\
\hline H6- & $0.00 \mathrm{c} \mathrm{B}$ & $0.09 \mathrm{~d} \mathrm{~B}$ & $0.65 \mathrm{~d} A$ & $0.00 \mathrm{c} \mathrm{B}$ & $0.04 \mathrm{~d} \mathrm{~B}$ & 0.39 e A \\
\hline
\end{tabular}

Overall mean values per location

$$
156.96
$$

250.23

131.43

40.05

116.41

${ }^{\mathrm{z}}$ Mean separations within each location by LSD at $P \leq 0.05$. Means followed by the same lower case letters are not significantly different.

${ }^{\mathrm{y}}$ Mean separations across locations by LSD at $P \leq 0.05$. Means followed by the same upper case letters are not significantly different.

FW = fresh weight; $\mathrm{CS}=$ College Station; $\mathrm{UV}=$ Uvalde; WE = Weslaco; $\mathrm{NA}=$ entry not available in that location; LSD = least significant difference.

Table 5. Flavonoid (quercetin and luteolin) concentrations in mature Habanero pepper fruits (C. chinense) grown in three Texas locations.

\begin{tabular}{|c|c|c|c|c|c|c|}
\hline \multirow[b]{2}{*}{ Genotype } & \multicolumn{3}{|c|}{ Quercetin concn $\left(\mu \mathrm{g} \cdot \mathrm{g}^{-1} \mathrm{FW}\right)$} & \multicolumn{3}{|c|}{ Luteolin concn $\left(\mu \mathrm{g} \cdot \mathrm{g}^{-1} \mathrm{FW}\right)$} \\
\hline & $\mathrm{CS}$ & UV & WE & $\mathrm{CS}$ & UV & WE \\
\hline Kuk-orange & $19.13 \mathrm{a}^{\mathrm{z}} \mathrm{A}^{\mathrm{y}}$ & NA & 8.21 a B & $2.88 \mathrm{~b} \mathrm{~A}$ & NA & $9.35 \mathrm{a} \mathrm{A}$ \\
\hline H1-red & $3.87 \mathrm{~b} \mathrm{AB}$ & $5.67 \mathrm{a} \mathrm{A}$ & $2.74 \mathrm{c} \mathrm{B}$ & $0.00 \mathrm{~b} \mathrm{~A}$ & $0.04 \mathrm{~d} \mathrm{~A}$ & $0.06 \mathrm{~b} \mathrm{~A}$ \\
\hline H2-orange & $8.49 \mathrm{~b} \mathrm{~A}$ & 4.53 a $\mathrm{A}$ & $5.19 \mathrm{~b} \mathrm{~A}$ & $5.36 \mathrm{ab} \mathrm{AB}$ & 7.36 a $\mathrm{A}$ & $3.03 \mathrm{~b} \mathrm{~B}$ \\
\hline H3-orange & $11.44 \mathrm{ab} \mathrm{A}$ & $4.50 \mathrm{a} \mathrm{B}$ & $6.51 \mathrm{ab} \mathrm{B}$ & $9.61 \mathrm{a} A$ & $5.37 \mathrm{~b} \mathrm{~B}$ & $3.82 \mathrm{~b} \mathrm{~B}$ \\
\hline H5-dark orange & $6.74 \mathrm{~b} \mathrm{~A}$ & $1.63 \mathrm{~b} \mathrm{~B}$ & $1.70 \mathrm{c} \mathrm{B}$ & $10.20 \mathrm{a} \mathrm{A}$ & $1.62 \mathrm{c} \mathrm{B}$ & $0.75 \mathrm{~b} \mathrm{~B}$ \\
\hline H6-yellow & $11.61 \mathrm{ab} A$ & $2.40 \mathrm{~b} \mathrm{~B}$ & $1.49 \mathrm{c} \mathrm{B}$ & $1.73 \mathrm{~b} \mathrm{~A}$ & $2.30 \mathrm{c} \mathrm{A}$ & $0.00 \mathrm{~b} \mathrm{~B}$ \\
\hline \multicolumn{7}{|c|}{ Overall mean values per location } \\
\hline & 10.21 & 3.75 & 4.31 & 4.96 & 3.34 & 2.84 \\
\hline
\end{tabular}

${ }^{\mathrm{z}}$ Mean separations within each location by LSD at $P \leq 0.05$. Means followed by the same lower case letters are not significantly different.

${ }^{y}$ Mean separations across locations by LSD at $P \leq 0.05$. Means followed by the same upper case letters are not significantly different.

FW = fresh weight; CS = College Station; UV = Uvalde; WE = Weslaco; NA = entry not available in that location; LSD = least significant difference. of the phytochemical expression within fruit tissue, but we believe it is a combination of different components. College Station did not appear to have the highest average values for any of the environmental parameters measured in this experiment except the precipitation parameter during the July month (Figs. 1 to 4 ). However, we believe the combination of the components (soil type, temperature, relative humidity, solar radiation, and precipitation), in addition to other unknown factors such as residual fertility and organic matter, led to the positive flavonoid trend at College Station. In this particular location, Kuk-orange produced the highest amount of quercetin followed by H6-yellow and H3-orange, whereas H1-red produced the lowest amount. In Uvalde, H1red produced the highest levels of quercetin followed by $\mathrm{H} 2$-orange and $\mathrm{H} 3$-orange, whereas H5-dark orange produced the lowest amount. In Weslaco, Kuk-orange produced the highest amount of quercetin followed by $\mathrm{H} 3$-orange and $\mathrm{H} 2$-orange, whereas the remaining genotypes were all comparably low in their respective concentrations (Table 5). For the luteolin data, inconsistent variation of genotypes across locations were found making it difficult to conclude which location was the best (Table 5). The ANOVA showed a significant F-value only for the $\mathrm{L} \times \mathrm{G}$ component of variance (Table 2). In College Station, H5-dark orange produced the highest amount of luteolin followed by H3-orange and $\mathrm{H} 2$-orange, whereas $\mathrm{H} 1$-red produced the lowest amount. In Uvalde, H2-orange produced the highest levels of luteolin followed by H3-orange and H6-yellow, whereas H1red produced the lowest amount. In Weslaco, Kuk-orange produced the highest amount followed by $\mathrm{H} 3$-orange and $\mathrm{H} 2$-orange, whereas H6-yellow produced the lowest (Table 5). As seen in Table 5, genotypes with the highest mean values produced higher and more favorable differences when compared with their overall mean values for each location.

Genotype by location impact on phytochemical concentrations and quality characteristics. Results from our preliminary correlation ( $r$ ) analyses produced values of $0.24,-0.56,-0.11$, and -0.77 when fruit number per plant and the two phytochemical groups (capsaicinoids and flavonoids) were analyzed as well as when fruit weight and the two phytochemical groups were analyzed, respectively (Table 1). Later, correlation analysis between capsaicinoids and flavonoids produced a value of 0.36 and identified $13.2 \%$ of the variability of total capsaicinoids (capsaicin + DHC) to be explained by total flavonoids (quercetin + luteolin). In all of these cases, we were able to conclude that there were not any significant associations between any of these comparisons. According to Hartley's HOV test, data analyzed within individual locations found the variances of each measurement to be significant and therefore heterogeneous. When data were analyzed across locations, only the variance of the fruit weight measurement was non-significant and therefore homogeneous. These results may be 
the result of significantly variable values produced for each characteristic. Fruit harvested from the Weslaco location was larger in size than fruit from the other two locations. Significant improvement in fruit size for these different genotypes may have been the result of the material's genetic potential, the specific environment, and improved cultural practices available in Weslaco that actually promoted fruit development more successfully than the other two locations. Results from this experiment also identified the Weslaco location as being the most optimum for producing Habanero fruit expressing higher levels of capsaicinoids. Therefore, exposing Habanero peppers to an environment similar to Weslaco would potentially produce fruit with higher levels of capsaicinoids, provided all other factors (pepper genotype, stage of maturity, and generation stage) were fixed. In contrast, an environmental location similar to College Station may be an optimum environment to produce Habanero fruit with higher levels of flavonoids. Although these assumptions may be difficult to meet as a result of the unpredictability of the weather from year to year, they can serve as guidance for producers interested in maximizing Habanero fruit quality. As reported by previous researchers (Harvell and Bosland, 1997; Lee et al., 2005; Zewdie and Bosland, 2000), a significant genotype $\times$ environment $(\mathrm{G} \times \mathrm{E})$ interaction can potentially exist with respect to concentrations of different phytochemicals present in pepper fruit tissue when planted in different environmental locations. Although only one line was evaluated, Harvell and Bosland (1997) reported a variability range in pungency levels from the highest plant to the lowest in excess of 6000 Scoville Heat Units, signifying the relative contribution a particular environment can have on variation observed in phytochemical expression. Previous reports by Lee et al. (2005) and Leskovar et al. (2009) suggest that variations in phytochemical expression are the result of environmental differences and can be the result of changes in daytime and nighttime temperatures, soil type, elevation, cultural practices, solar radiation, and precipitation. Therefore, choosing the appropriate combination of environment and genotype will potentially assist in production of the highest quality pepper fruit for consumers.

\section{Conclusions}

In an effort to develop improved Habanero genotypes that address current and future trends of the industry, breeders need to focus on creation of material with larger fruit, elevated phytochemicals, and disease resistance. From our results, we were able to identify some genotypes that have potential to exhibit these related traits and be readily accepted by the industry. Our conclusions also strengthened previous reports by Lee et al. (2005) indicating that the Weslaco environment may have impacted the genetic capacity of plants to successfully produce larger fruit with higher amounts of capsaicinoids. H5-dark orange was identified as performing the most consistently in the different locations and producing capsaicinoid levels comparable to Kuk-orange (standard), whereas H6-yellow produced the lowest comparable to the standard TMH (Crosby et al., 2005). In comparison with the overall mean values obtained from each location, H5-dark orange's mean was significantly higher, whereas H6yellow's mean was significantly lower in all cases. These observations could, therefore, lead to H5-dark orange being a potential candidate for markets where hot, pungent Habanero peppers are valued and H6-yellow being another mild option for consumers who desire a product low in "heat." Although flavonoid results from this experiment were found to be relatively low as previously mentioned (Howard et al., 2000), we feel as though H3-orange may exhibit the most stable performance of these experimental hybrids to more closely compete against the commercial control and be used for various markets where this trait is important. It is possible that our low flavonoid results were the result of the convergence of the phenylpropanoid and capsaicinoid biosynthetic pathways during fruit maturation (Materska and Perucka, 2005; Sukrasno and Yeoman, 1993). As previously mentioned by Howard (2001), it may be possible that different phenolic precursors were diverted from flavonoids to capsaicinoids and why a decrease in flavonoid concentrations are usually found in fruit tissue of material generally having higher capsaicinoid levels.

This experiment also complements results from previous studies (Harvell and Bosland, 1997; Lee et al., 2005; Zewdie and Bosland, 2000 ) showing both genotype and genotype $x$ environment components impacting phytochemical expression in peppers. Identification of the appropriate environmental location to grow a specific pepper genotype is an important factor to produce the highest quality product. Changing the environmental location can affect not only the size of marketable fruit, but also levels of different phytochemicals present within fruit tissue. Therefore, we conclude that the new Habanero material described herein can potentially compete against commercial cultivars for fruit weight, capsaicinoid, and flavonoid levels as well as disease resistance.

\section{Literature Cited}

Amiot-Carlin, M.J., A. Margotat, and F. Tourniaire. 2007. Flavonoids in food and wine, p. 107-116. In: Desjardins, Y. (ed.). Proc. 1st Intl. Symp. Human Health Effects of F\&V. Acta Hort., 744, ISHS.

Andrews, J. 1995. Peppers: The domesticated Capsicums. University of Texas Press, Austin, TX.

Antonious, G.F., L. Lobel, T. Kochhar, T. Berke, and R.L. Jarret. 2009. Antioxidants in Capsicum chinense: Variation among countries of origin. J. Environ. Sci. Health B 44:621-626.

Ben-Chaim, A., Y. Borovsky, M. Falise, M. Mazourek, B.C. Kang, I. Paran, and M. Jahn. 2006. QTL analysis for capsaicinoid content in Capsicum. Theor. Appl. Genet. 113:1481-1490.

Contreras-Padilla, M. and E.M. Yahia. 1998. Changes in capsaicinoids during development, maturation, and senescence of chile peppers and relation with peroxidase activity. J. Agr. Food Chem. 46:2075-2079.

Cooper, T.H., J.A. Guzinski, and C. Fisher. 1991. Improved high-performance liquid chromatography method for the determination of major capsaicinoids in Capsicum oleoresins. J. Agr. Food Chem. 39:2253-2256.

Crosby, K.M. 2008. Pepper, p. 221-248. In Prohens, J. and F. Nuez (eds.). Vegetables, II: Fabaceae, Liliaceae, Umbelliferae, and Solanaceae. Springer, New York, NY.

Crosby, K.M., D.I. Leskovar, and K.S. Yoo. 2005. 'TAM Mild Habanero,' a low pungency Habanero pepper. HortScience 40:490-491.

de Sousa, J.A. and W.R. Maluf. 2003. Diallel analyses and estimation of genetic parameters of hot pepper (Capsicum chinense Jacq.). Scientia Agrícola 60:105-113.

Fery, R.L. and Thies, J.A. 2006. Notice of release of 'Tigerpaw-Nr', a root-knot nematode resistant, Habanero-type pepper. USDA, Agricultural Research Service, Cultivar Release, 9 Jan.

Greenleaf, W.H. 1986. Pepper breeding. In: Bassett, M.J. (ed.). Breeding vegetable crops. AVI Publishing Co., Westport, CT.

Harvell, K.P. and P.W. Bosland. 1997. The environment produces a significant effect on pungency of chiles. HortScience 32:1292.

Havsteen, B. 1983. Commentary: Flavonoids, a class of natural products of high pharmacological potency. Biochem. Pharmacol. 32:1141-1148.

Hertog, M.G.L., P.C.H. Hollman, and D.P. Venema. 1992. Optimization of a quantitative HPLC determination of potentially anticarcinogenic flavonoids in vegetables and fruits. J. Agr. Food Chem. 40:1591-1598.

Hollman, P.C. and M.B. Katan. 1999. Dietary flavonoids: Intake, health effects and bioavailability. Food Chem. Toxicol. 37:937-942.

Hoshmand, A.R. 2006. Single-factor experimental designs, p. 27. In: Design of experiments for agriculture and the natural sciences. 2nd Ed. Taylor \& Francis Group, LLC., Boca Raton, FL.

Howard, L.R. 2001. Antioxidant vitamin and phytochemical content of fresh and processed pepper fruit (Capsicum annuum), p. 209-233. In: Wildman, R.C. (ed.). Handbook of nutraceuticals and functional foods. CRC Press, Boca Raton, FL.

Howard, L.R., S.T. Talcott, C.H. Brenes, and B. Villalon. 2000. Changes in phytochemical and antioxidant activity of selected pepper cultivars (Capsicum species) as influenced by maturity. J. Agr. Food Chem. 48:1713-1720.

Huffman, V.L. 1977. Volatile components and pungency in fresh and processed jalapeño peppers (Capsicum annuum). PhD diss., Texas A\&M University, College Station, TX.

Kurian, A.L. and A.N. Starks. 2002. HPLC analysis of capsaicinoids extracted from whole orange Habanero chili peppers. J. Food Sci. 67:956962.

Lee, J.J., K.M. Crosby, L.M. Pike, K.S. Yoo, and D.I. Leskovar. 2005. Impact of genetic and environmental variation on development of flavonoids and carotenoids in pepper (Capsicum spp.). Sci. Hort. 106:341-352.

Lee, Y., L.R. Howard, and B. Villalon. 1995 Flavonoids and antioxidant activity of fresh pepper (Capsicum annuum) cultivars. J. Food Sci. 60:1-4.

Leskovar, D.I., K. Crosby, and J.L. Jifon. 2009. Impact of agronomic practices on phytochemicals and quality of vegetable crops. Acta Hort. 841:317-322.

Materska, M. and I. Perucka. 2005. Antioxidant activity of the main phenolic compounds isolated 
from hot pepper fruit (Capsicum annuum L.). J. Agr. Food Chem. 53:1750-1756.

Milerue, N. and Nikornpun, M. 2000. Studies on heterosis of chili (Capsicum annuит L.). Kasetsart J. (Nat. Sci.) 34:190-196.

Monforte-Gonzalez, M., A. Guzman-Antonio, F. Uuh-Chim, and F. Vazquez-Flota. 2010. Capsaicin accumulation is related to nitrate content in placentas of Habanero peppers (Capsicum chinense Jacq.). J. Sci. Food Agr. 90:764-768.

Pietta, P.G. 2000. Flavonoids as antioxidants. J. Nat. Prod. 63:1035-1042.
Poyrazoglu, E.S., O. Yemis, C. Kadakal, and N. Artik. 2005. Determination of capsaicinoid profile of different chilli peppers grown in Turkey. J. Sci. Food Agr. 85:1435-1438.

Ross, J.A. and C.M. Kasum. 2002. Dietary flavonoids: Bioavailability, metabolic effects, and safety. Annu. Rev. Nutr. 22:19-34.

Sanatombi, K. and G.J. Sharma. 2008. Capsaicin content and pungency of different Capsicum spp. cultivars. Not. Bot. Hort. Agrobot. Cluj 36:89-90.

SAS Institute Inc. 2008. SAS 9.2 users guide. 2nd Ed. SAS Institute Inc., Cary, NC.
Singh, S., R. Jarret, V. Russo, G. Majetich, J. Shimkus, R. Bushway, and B. Perkins. 2009. Determination of capsinoids by HPLC-DAD in Capsicum species. J. Agr. Food Chem. 57:3452-3457.

Sukrasno, N. and M.M. Yeoman. 1993. Phenylpropanoid metabolism during growth and development of Capsicum frutescens fruits. Phytochemistry 32:839-844.

Zewdie, Y. and P.W. Bosland. 2000. Evaluation of genotype, environment, and genotype-byenvironment interaction for capsaicinoids in Capsicum annuum L. Euphytica 111:185-190. 